\title{
Evaluation of the Clinical and Radiological Outcomes of Pulpotomized Primary Molars Treated with Three Different Materials: Mineral Trioxide Aggregate, Biodentine, and Pulpotec. An In-vivo Study
}

Raparla Mythraiye ${ }^{1}$, VV Rao ${ }^{1}$, MS Minor Babu ${ }^{1}$, Martha Satyam ${ }^{1}$, Punithavathy R. ${ }^{2}$, Chandrika Paravada 1

1. Pedodontics and Preventive Dentistry, Lenora Institute of Dental Sciences, Rajahmundry, IND 2. Pedodontics and Preventive Dentistry, Lenora Institute of Dental Sciences, Rajahmundry , IND

Corresponding author: Raparla Mythraiye, drmythi@gmail.com

\section{Abstract \\ Introduction}

The main treatment objective of pediatric dentistry lies in maintaining the integrity of the arches. The loss of primary teeth at an early age causes malocclusion. Primary teeth are considered the best space maintainers in the arch. Hence, every effort should be directed to preserve these teeth as far as possible. One of the most important goals of pediatric dentistry is the restoration of carious primary teeth and the maintenance of optimal oral health.

\section{Aim}

The aim of this study is to compare and evaluate different pulpotomy materials like mineral trioxide aggregate (MTA), Biodentine, and Pulpotec in primary molars.

\section{Materials and methods}

In the present study, 84 primary molars were selected for the pulpotomy procedure and randomly assigned to one of the three groups of MTA, Biodentine, and Pulpotec, allocating 28 primary molars to each group. The pulpotomy procedure was performed on all selected teeth and followed by permanent restoration with stainless steel crowns. All the molars were evaluated, both clinically and radiographically, at an interval of one, three, and six months.

\section{Results}

Received 04/21/2019

Review began 05/09/2019 Review ended 05/13/2019 Published 06/02/2019

๑) Copyright 2019 Mythraiye et al. This is an open access article distributed under the terms of the Creative Commons Attribution License CC-BY 3.0., which permits unrestricted use, distribution, and reproduction in any medium, provided the original author and source are credited.
At the end of the first month, there were no adverse clinical and radiographical findings observed in all three groups. At the end of the third month, Group I showed $96 \%$ clinical and radiographical success, Group II showed 100\% clinical and 96\% radiographical success, and Group III showed 100\% clinical and radiographical success. At the end of the sixth month, Group I showed $96 \%$ clinical and radiographical success, Group II showed 100\% clinical and 90\% radiographical success and Group III showed 100\% clinical and radiographical success. The observations were subjected to statistical analysis using Fisher's exact test and the Chi-square test.

\section{Conclusion}

MTA, Biodentine, and Pulpotec can be used as materials of choice for pulpotomy. Furthermore, Pulpotec appeared to be clinically and radiographically more successful than MTA and Biodentine.

Categories: Pain Management, Pediatrics, Other

Keywords: pulpotomy, mta, biodentine, pulpotec, formocresol, pulptherapy

\section{Introduction}

The goal of pediatric dentistry is maintaining arch integrity by preserving optimal oral health. Pulpotomy and pulpectomy are the two procedures for treating infected pulp tissue in order to prevent dental abscesses and loss of teeth.

Pulpotomy is conservative treatment performed to remove the inflamed coronal portion of the pulp by preserving the vitality of the remaining radicular pulp. Formocresol has been a popular pulpotomy medicament in the primary dentition and is still the most universally used pulp medicament for primary 


\section{Cureus}

teeth. The use of formocresol in humans raised several concerns, and alternatives have been proposed. Mineral trioxide aggregate (MTA), Biodentine, and Pulpotec are recently introduced materials that have been considered as alternatives to formocresol for pulpotomies in primary teeth with exposed pulps. The present study was aimed at evaluating and comparing the success of pulpotomy using MTA, Biodentine, and Pulpotec clinically and radiographically.

\section{Materials And Methods}

The present study was conducted in the Department of Pedodontics and Preventive Dentistry, Lenora Institute of Dental Sciences, Andhra Pradesh. Healthy children in the age group of five to nine years, with no history of systemic illness having restorable primary first and second molars, with deep carious lesions, were included in the study. Eighty-four primary molars were selected for the pulpotomy procedure and randomly assigned to one of the three groups, viz. MTA, Biodentine, and Pulpotec, allocating 28 primary molars to each group.

For each child, access preparation was done under local anesthesia and isolation. Following pulpal exposure, the superficial pulp was removed with a sterile, sharp spoon excavator. Samples were assigned randomly to one of the three groups. After achieving hemostasis, in Group I, MTA paste; in Group II, Biodentin; and in Group III, Pulpotec paste was placed in the pulp chamber and condensed lightly with a moistened cotton pellet. The teeth of the children in all three groups were filled with a thick layer of Zinc Oxide Eugenol, followed by Glass Ionomer Cement (GIC) type IX and a stainless steel crown within 10 days.

All cases were evaluated both clinically and radiographically after a period of one month, three months, and six months. Clinical success was defined as the absence of spontaneous pain, acute abscess, fistula, or excessive mobility. Radiographic success was defined as the presence of a normal periodontal ligament space, the absence of furcal radiolucency, pathologic root resorption, or root canal calcification. All the molars were evaluated at an interval of one, three, and six months.

Figures 1-3 show the radiographs for teeth treated with MTA.

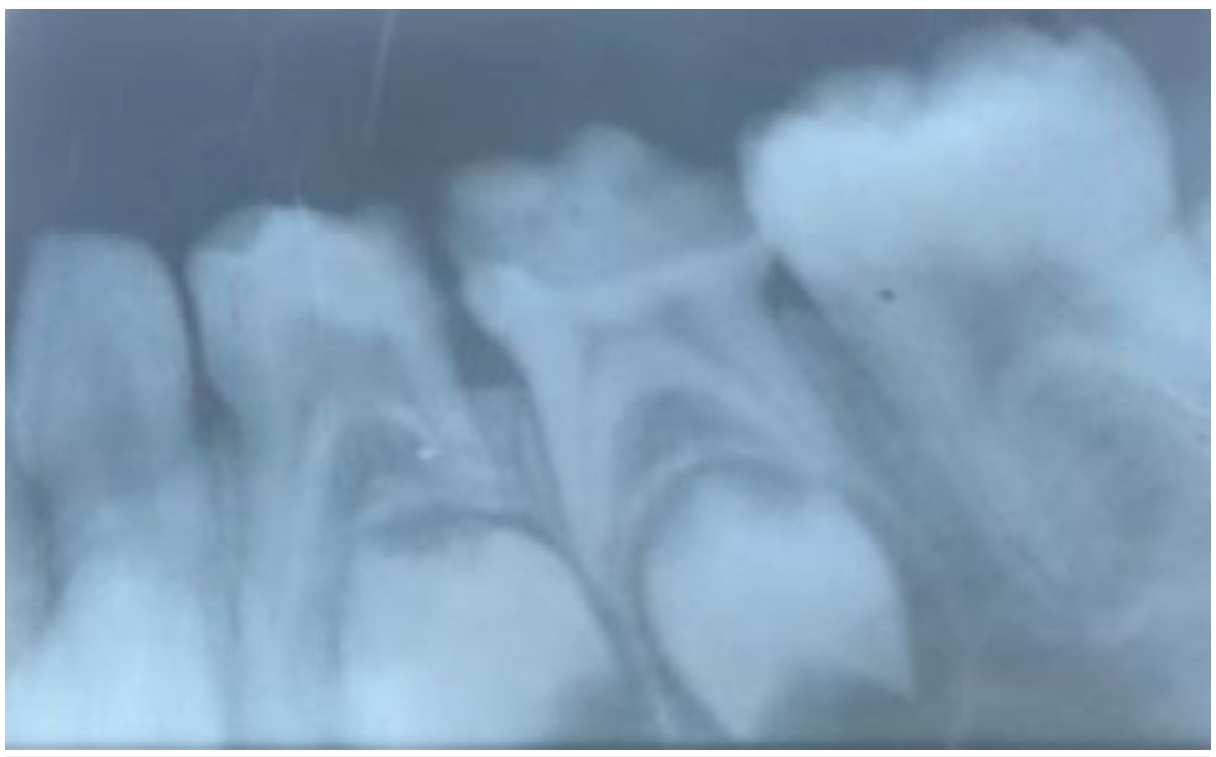

FIGURE 1: Preoperative radiograph for the placement of MTA

MTA: Mineral Trioxide Aggregate 


\section{Cureus}

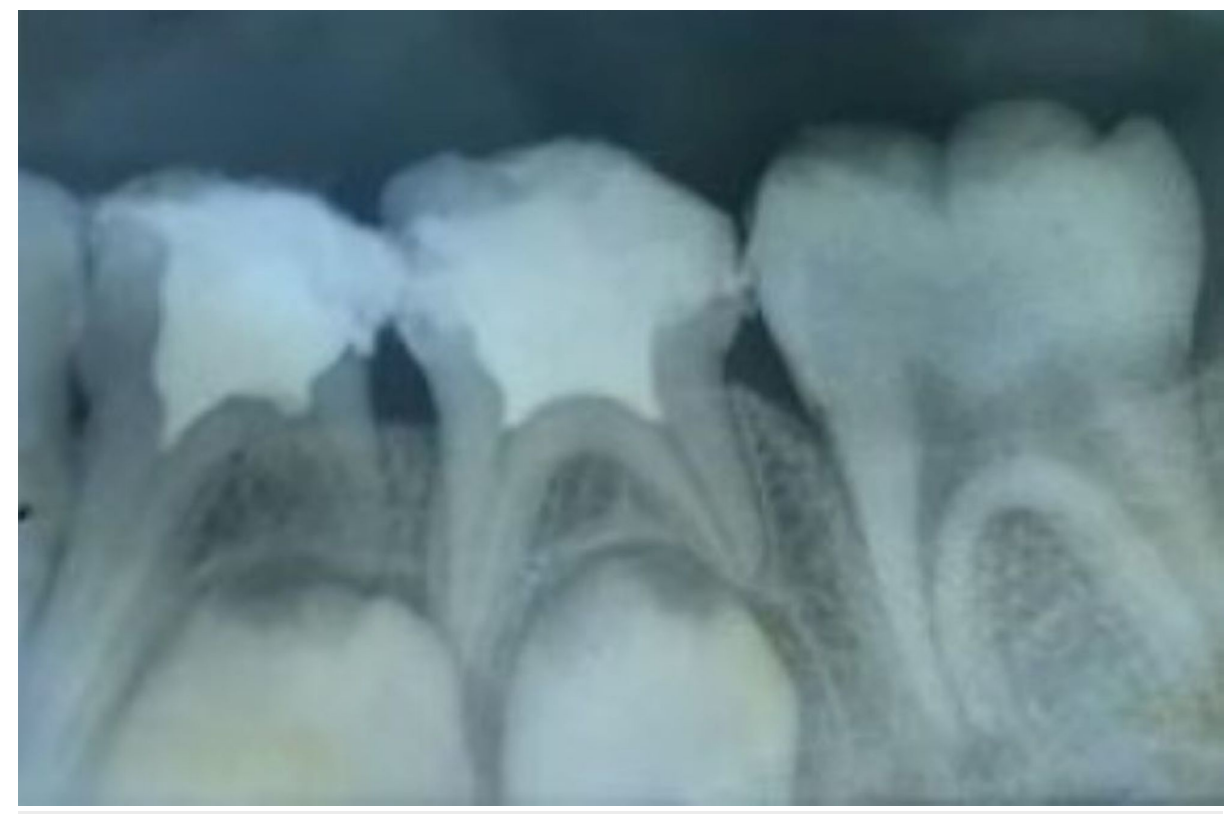

FIGURE 2: Postoperative radiograph after the placement of MTA

MTA - Mineral Trioxide Aggregate

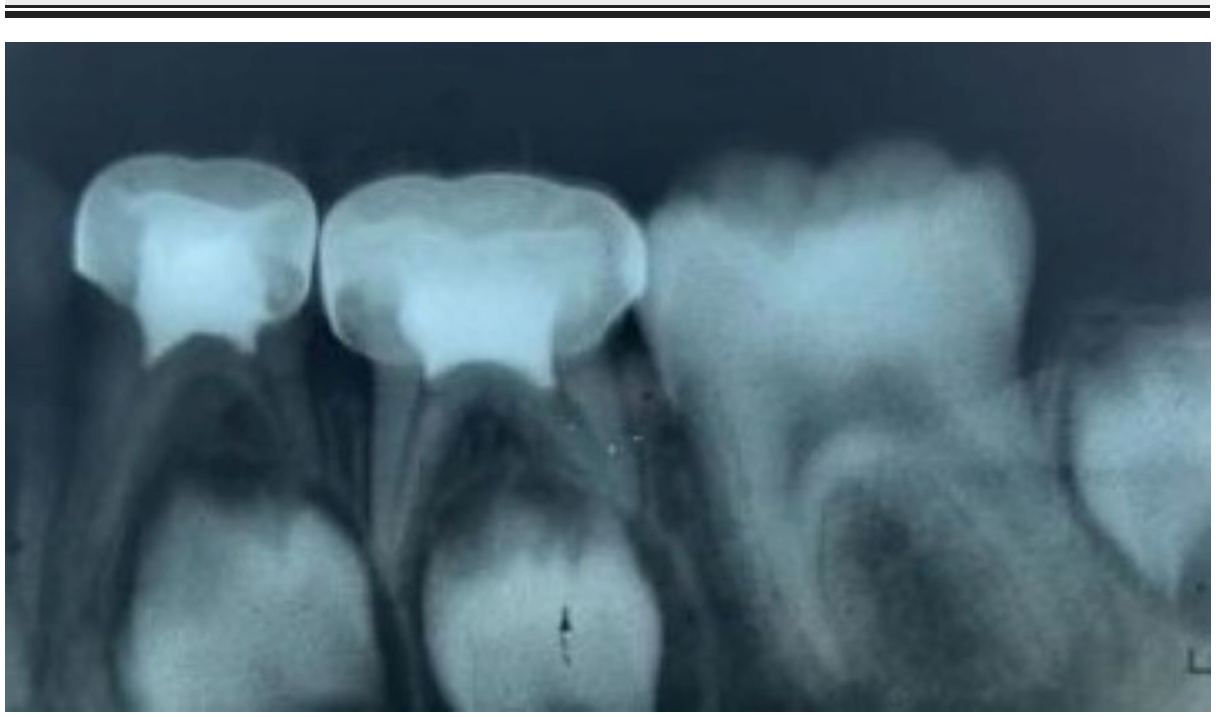

FIGURE 3: Three months follow-up after the placement of MTA

MTA - Mineral Trioxide Aggregate

Figures 4-6 show the radiographs for teeth treated with Biodentine. 


\section{Cureus}

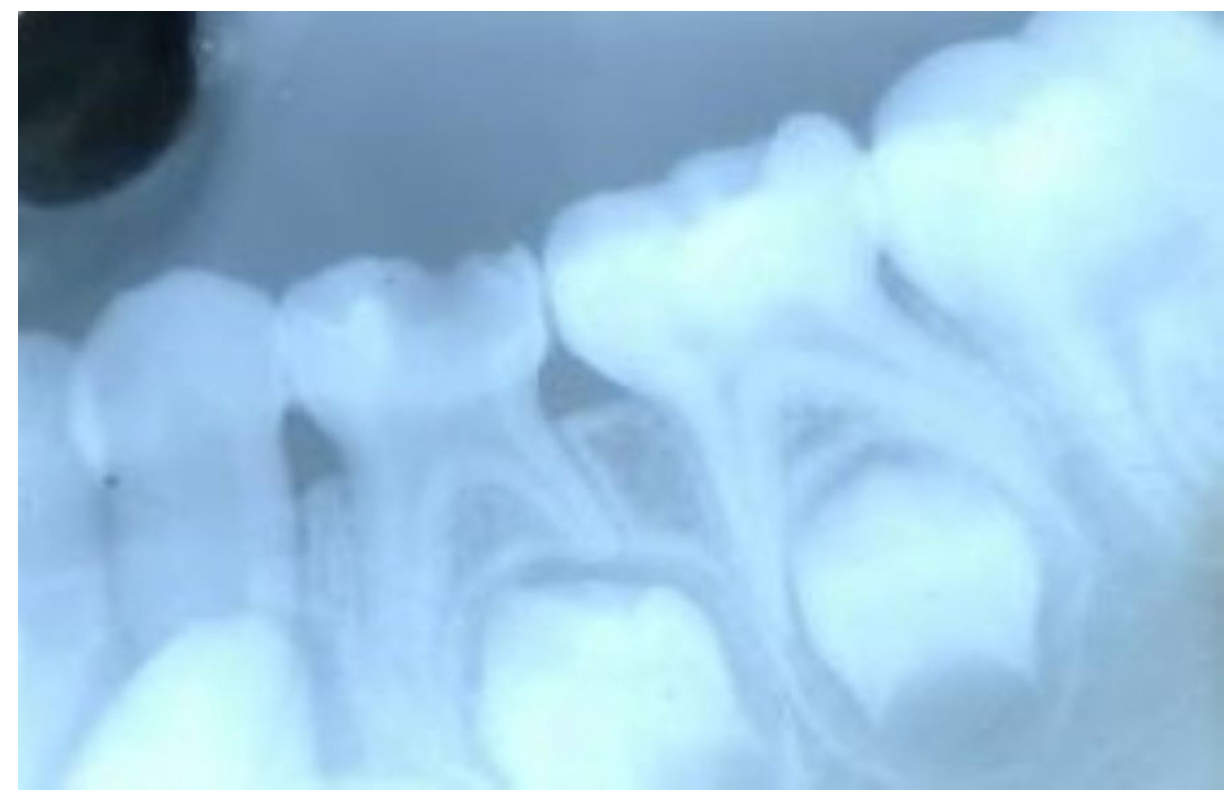

FIGURE 4: Preoperative radiograph for the placement of Biodentine

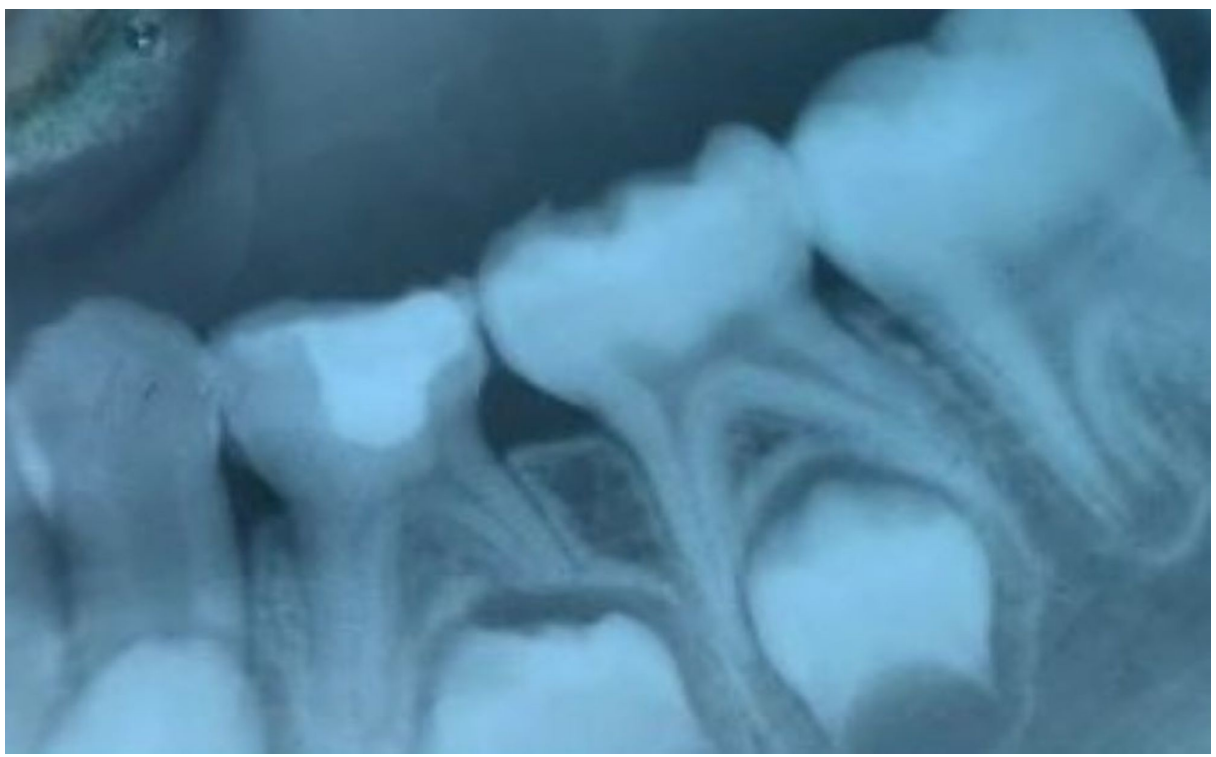

FIGURE 5: Postoperative radiograph after the placement of Biodentine 


\section{Cureus}

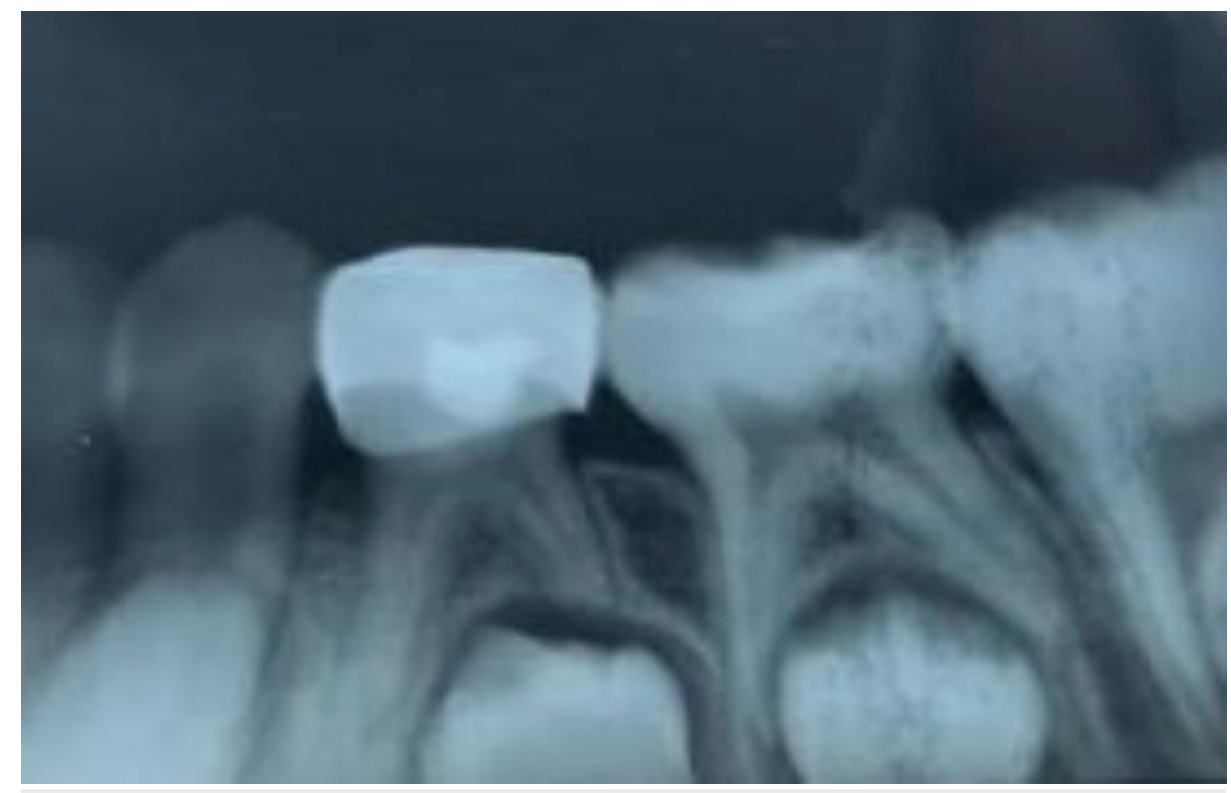

FIGURE 6: Three months follow-up after the placement of Biodentine

Figures 7-9 show the radiographs of teeth treated with Pulpotec.

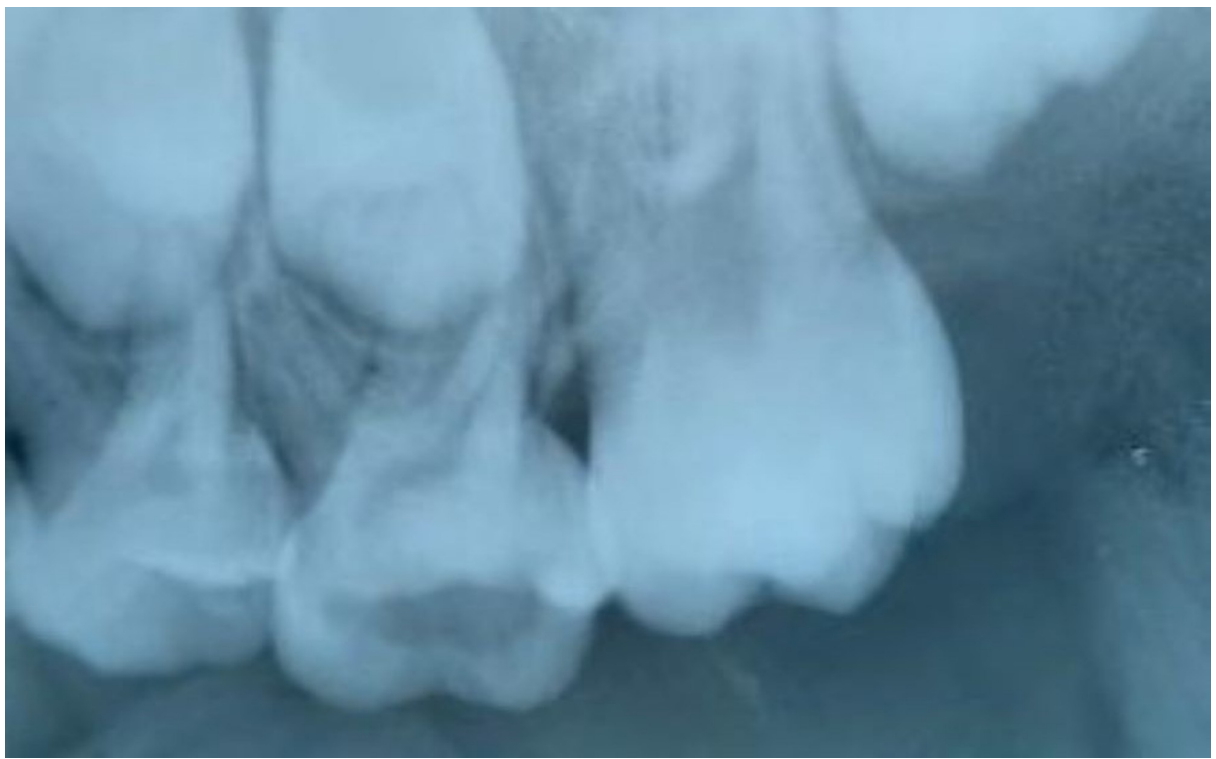

FIGURE 7: Preoperative radiograph for the placement of Pulpotec 


\section{Cureus}

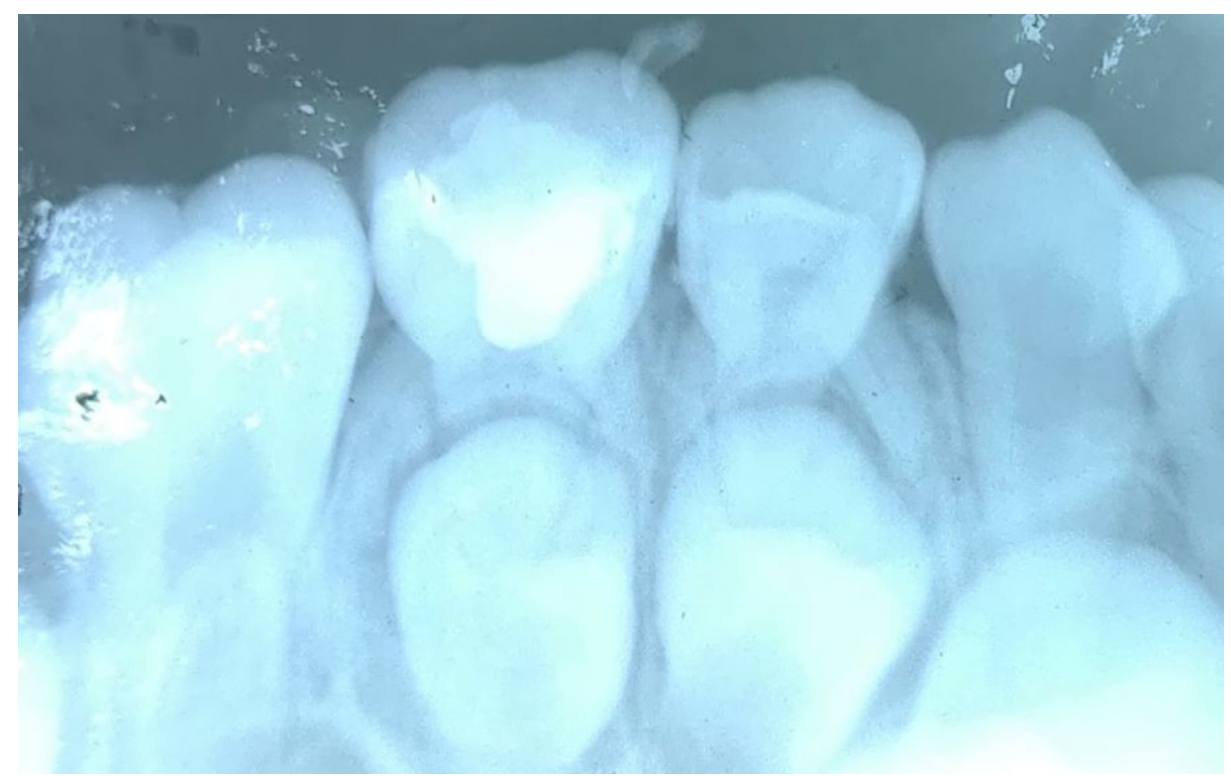

FIGURE 8: Postoperative radiograph after the placement of Pulpotec

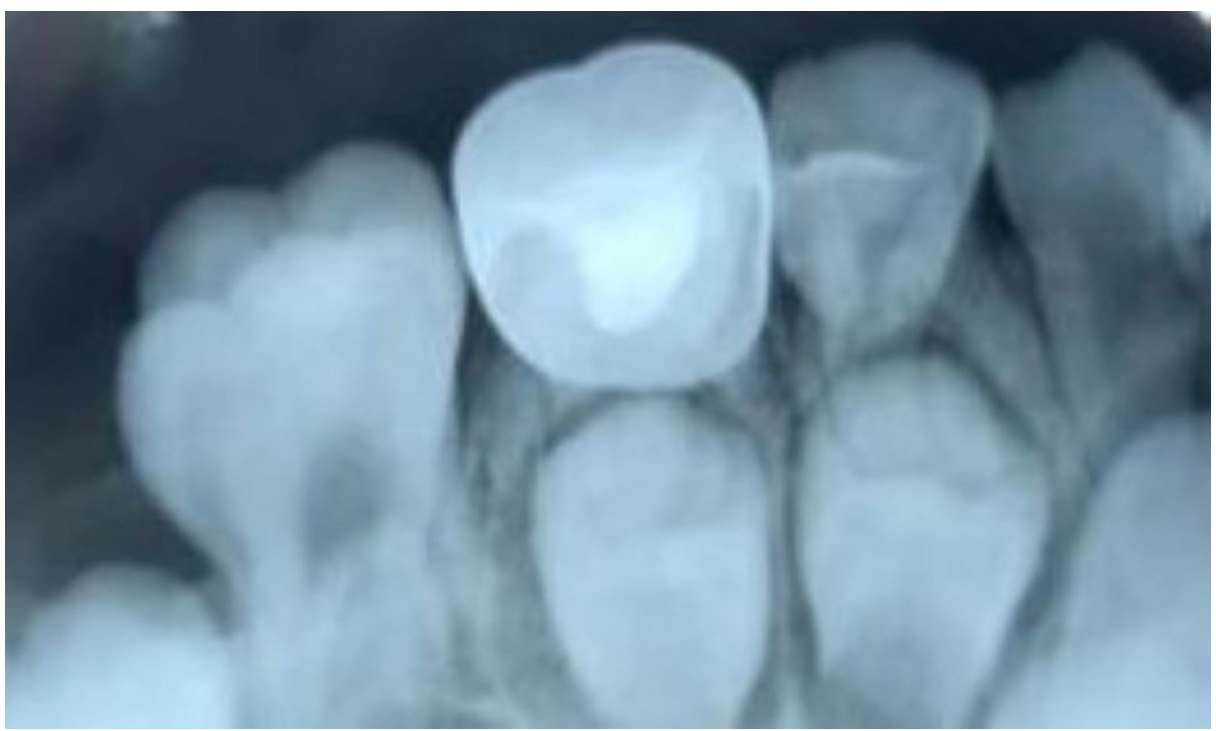

FIGURE 9: Three months follow-up after the placement of Pulpotec

\section{Results}

At the end of the first month, there were no negative clinical and radiographical findings observed in all three groups. By the end of one month, eight molars were lost to follow-up. After three months, 17 were lost and this number increased to 21 after six months (Table 1). 


\section{Cureus}

\begin{tabular}{|c|c|c|c|}
\hline Follow-up & MTA & BIODENTINE & PULPOTEC \\
\hline Starting & 28 & 28 & 28 \\
\hline $1^{\text {st }}$ month & 27 & 25 & 24 \\
\hline $3^{\text {rd }}$ month & 22 & 21 & 24 \\
\hline $6^{\text {th }}$ month & 22 & 21 & 20 \\
\hline
\end{tabular}

\section{TABLE 1: Follow-up at the first, third, and sixth months}

MTA - Mineral Trioxide Aggregate

Among the 63 teeth that were clinically evaluated after the first, third, and sixth months, one tooth in Group I showed pain, swelling, sinus tract, and mobility by the end of three months. MTA (Group I) showed 96\% clinical success by the end of three months, whereas teeth treated with Biodentine (Group II) and Pulpotec (group III) revealed no abnormal clinical findings by the end of six months. Thus, Biodentine and Pulpotec showed $100 \%$ clinical success by the end of six months (Table 2 ).

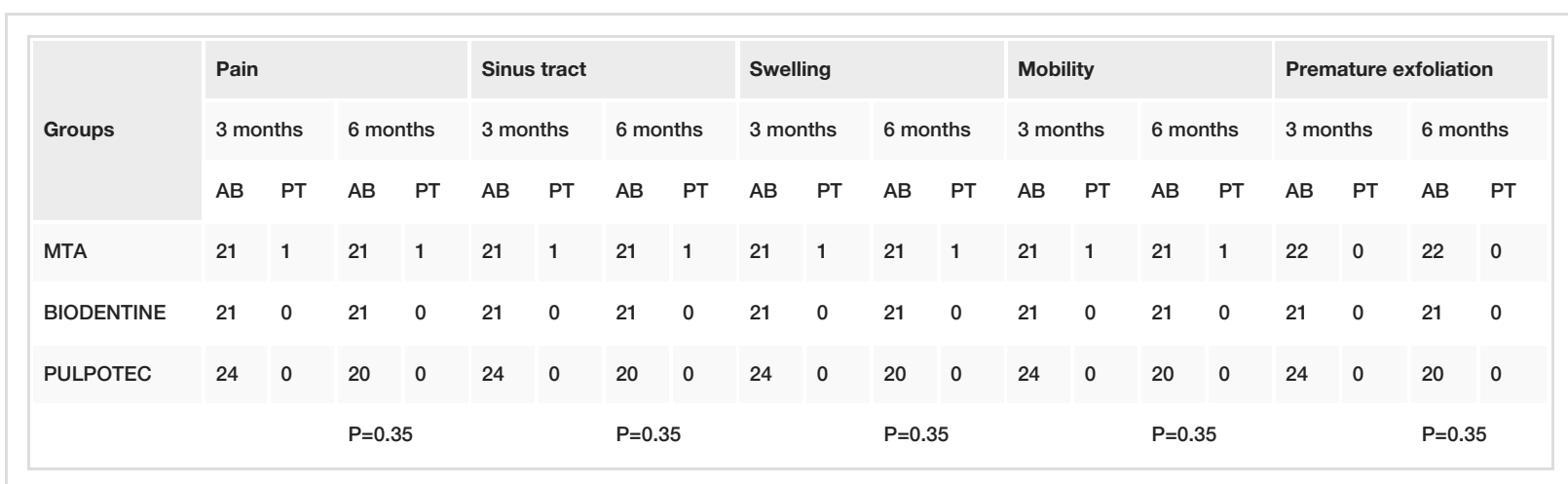

TABLE 2: Comparison of the clinical parameters of the three study groups

AB - Absent; PT - Present; MTA - Mineral Trioxide Aggregate

On radiographical evaluation after the first, third, and sixth months, one tooth in Group I showed periodontal ligament widening and periapical radiolucency at the end of three months. MTA (Group I) showed $96 \%$ radiographical success by the end of three months. Among the teeth treated with Biodentine (Group II), two teeth showed periodontal ligament widening - one at the end of the third month and another at the end of the sixth month. Thus, Group II showed $90 \%$ radiographical success by the end of six months. In the case of teeth treated with Pulpotec (group III), no teeth revealed abnormal radiographical findings by the end of six months. Thus, Group III showed 100\% radiographical success by the end of six months (Table 3). 


\section{Cureus}

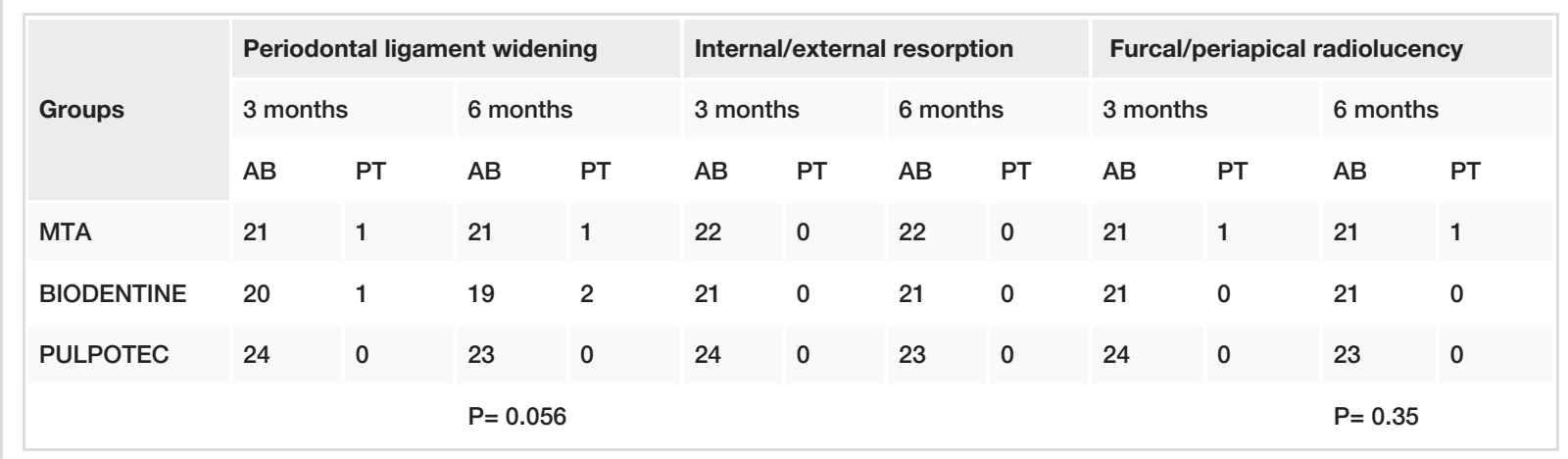

\section{TABLE 3: Comparison of the radiographical parameters of the three study groups}

AB - Absent; PT - Present; MTA - Mineral Trioxide Aggregate

A comparison of clinical criteria, i.e., status of pain, sinus tract, swelling, mobility, and premature exfoliation at the end of three and six months showed a non-significant difference $(p>0.05)$ for each material (Tables 4-5). A comparison of radiographical criteria, i.e., periodontal ligament space widening, internal/external resorption, and furcal/periapical radiolucency at three- and six-month intervals also showed a non-significant difference $(\mathrm{p}>0.05)$ for each material (Tables $4-5)$.

\begin{tabular}{|c|c|c|c|c|c|c|c|c|}
\hline \multirow{2}{*}{ Parameter } & \multicolumn{2}{|c|}{$\begin{array}{l}\text { Group I MTA } \\
(n=22)\end{array}$} & \multicolumn{2}{|c|}{$\begin{array}{l}\text { Group II BIODENTINE } \\
(\mathrm{n}=\mathbf{2 1})\end{array}$} & \multicolumn{2}{|c|}{$\begin{array}{l}\text { Group III PULPOTEC } \\
(n=24)\end{array}$} & \multicolumn{2}{|c|}{$\begin{array}{l}\text { Significance of } \\
\text { difference }\end{array}$} \\
\hline & $\mathrm{n}$ & percentage & $\mathbf{n}$ & percentage & $\mathbf{n}$ & percentage & $x^{2}$ & $\mathrm{p}$ \\
\hline \multicolumn{9}{|l|}{ Clinical parameters } \\
\hline Pain & 1 & 4.5 & 0 & 0 & 0 & 0 & 2.076 & 0.354 \\
\hline Sinus tract & 1 & 4.5 & 0 & 0 & 0 & 0 & 2.076 & 0.354 \\
\hline Swelling & 1 & 4.5 & 0 & 0 & 0 & 0 & 2.076 & 0.354 \\
\hline Mobility & 1 & 4.5 & 0 & 0 & 0 & 0 & 2.076 & 0.354 \\
\hline Premature exfoliation & 0 & 0 & 0 & 0 & 0 & 0 & ------ & ----- \\
\hline \multicolumn{9}{|l|}{ Radiographical parameters } \\
\hline $\begin{array}{l}\text { Periodontal ligament } \\
\text { widening }\end{array}$ & 1 & 4.5 & 1 & 4.8 & 0 & 0 & 1.152 & 0.562 \\
\hline Internal/external resorption & 0 & 0 & 0 & 0 & 0 & 0 & ----- & ------ \\
\hline $\begin{array}{l}\text { Furcal/periapical } \\
\text { radiolucency }\end{array}$ & 1 & 4.5 & 0 & 0 & 0 & 0 & 2.076 & 0.354 \\
\hline
\end{tabular}

\section{TABLE 4: Postoperative evaluation after three months}

MTA - Mineral Trioxide Aggregate 


\section{Cureus}

\begin{tabular}{|c|c|c|c|c|c|c|c|c|}
\hline \multirow{2}{*}{ Parameter } & \multicolumn{2}{|c|}{$\begin{array}{l}\text { Group IMTA } \\
(n=22)\end{array}$} & \multicolumn{2}{|c|}{$\begin{array}{l}\text { Group II BIODENTINE } \\
(n=21)\end{array}$} & \multicolumn{2}{|c|}{$\begin{array}{l}\text { Group III PULPOTEC } \\
(n=20)\end{array}$} & \multicolumn{2}{|c|}{$\begin{array}{l}\text { Significance of } \\
\text { difference }\end{array}$} \\
\hline & $\mathrm{n}$ & percentage & $\mathrm{n}$ & percentage & $\mathrm{n}$ & percentage & $x^{2}$ & $\mathbf{p}$ \\
\hline \multicolumn{9}{|l|}{ Clinical parameters } \\
\hline Pain & 1 & 4.5 & 0 & 0 & 0 & 0 & 1.894 & 0.38 \\
\hline Sinus tract & 1 & 4.5 & 0 & 0 & 0 & 0 & 1.894 & 0.38 \\
\hline swelling & 1 & 4.5 & 0 & 0 & 0 & 0 & 1.894 & 0.38 \\
\hline Mobility & 1 & 4.5 & 0 & 0 & 0 & 0 & 1.894 & 0.38 \\
\hline Premature exfoliation & 1 & 4.5 & 0 & 0 & 0 & 0 & 1.894 & 0.38 \\
\hline \multicolumn{9}{|l|}{ Radiographical parameters } \\
\hline $\begin{array}{l}\text { Periodontal ligament } \\
\text { widening }\end{array}$ & 1 & 4.5 & 2 & 9.5 & 0 & 0 & 2.052 & 0.358 \\
\hline Internal/external resorption & 0 & 0 & 0 & 0 & 0 & 0 & ------- & ------ \\
\hline $\begin{array}{l}\text { Furcal/periapical } \\
\text { radiolucency }\end{array}$ & 1 & 4.5 & 0 & 0 & 0 & 0 & 1.894 & 0.38 \\
\hline
\end{tabular}

TABLE 5: Postoperative evaluation after six months

\section{Discussion}

Vital pulpotomy is considered a one-stage procedure with the objective of preserving the vitality and function of the remaining radicular portion of pulp and keeping it asymptomatic without adverse clinical signs such as sensitivity, pain, or swelling [1]. The ideal pulpotomy medicament and/or technique should be bio-inductive or at least biocompatible, bactericidal, and harmless to the pulp and surrounding structures [2].

Formocresol has been a popular pulpotomy medicament in the primary dentition and is still universally used in pulpal therapy for primary teeth. Despite its wide usage, formocresol has several disadvantages apart from not being ideal pulpotomy medicament. Concerns have been raised by several researchers over the use of formocresol in humans [3], and several alternatives have been proposed like mineral trioxide aggregate, Biodentine, and Pulpotec.

In search of ideal pulpotomy medicament, materials like mineral trioxide aggregate, Biodentine, and Pulpotec have been tried in the present study with variable clinical and radiological success.

The success rate of MTA in the present study has been promising with $96 \%$ of clinical and radiographical success in six months. The results of the study are comparable to other contemporary studies.

A similar study comparing the clinical and radiographic success rates for formocresol and MTA pulpotomy in primary molars was $83 \%$ and $97 \%$, respectively [4]. Another study comparing the clinical and radiographical success of formocresol and MTA in which, at the end of 12 months, the clinical outcome of formocresol was $91.3 \%$ and MTA was $100 \%$. The radiographical outcome of formocresol was $78.26 \%$ and MTA was $95.74 \%$. Periodontal ligament widening and inter-radicular radiolucency were seen in the formocresol group. The probable reason may be due to the fixative effect of formocresol and the ability of vapors to escape via the apical foramen. Failures of MTA can be attributed to a misdiagnosis of inflammation in the radicular pulp prior to treatment [5].

The failures that are seen by the subjects treated with MTA in the present study may be due to microleakage through the restoration and failure to place a stainless steel crown.

In the present study, Group II was treated with Biodentine, which showed $100 \%$ clinical success at the six months' follow-up whereas radiographical success was $96 \%$ by the end of three months and $91 \%$ by the end of six months.

Biodentine has several advantages, which include good sealing ability, adequate compressive strength, and short setting time, which provide a significant clinical advantage over other comparable materials [6]. 
In a similar study comparing MTA, laser, and Biodentin for pulpotomy, the results showed failure for two cases in the laser and Biodentine groups. They explained the reason for the failures might be due to iatrogenic errors like poorly adapted stainless steel crowns, a thin base, voids in the cement, and areas of residual caries or coronal pulp tissue. It is also quite possible that the laser pulpotomy is more sensitive to operator technique. They concluded that these materials are better alternatives to formocresol [7].

While considering material for clinical use, handling characteristics are very important. Biodentine received a better rating for material handling and performance after restoration placement because of its mechanical properties and setting time as compared to MTA. Biodentin has high compressive strength, antifungal and antimicrobial activity, and is less porous compared to MTA [8].

In this study, Group III, treated with Pulpotec, showed 100\% clinical and radiological success with the six months follow-up. Pulpotec is used for the rapid and long-term treatment of pulpitis by pulpotomy in vital molars, both primary and permanent [9].

A study conducted on histological evaluation following the usage of Pulpotec for pulpotomy procedure by Satygo revealed three zones next to the pulp-cement interface, which is similar to formocresol. Though Pulpotec and formocresol showed similar histological findings, due to the minimal concentration of formaldehyde in Pulpotec as compared to formocresol, Pulpotec is advisable over formocresol. Recent research on formaldehyde metabolism, pharmacokinetics, and carcinogenicity indicates that formaldehyde is probably not a potent human carcinogen under conditions of low exposure [10].

Pulpotec has the advantage of having clinical success even in cases with a little residual blood in the pulp chamber when used as a pulpotomy medicament. The results of Pulpotec are in agreement with Donskaya and Dedeyan's [11] clinical trials using Pulpotec as pulpotomy medicament and reported easiness and simplicity. The paste hardens quickly after the mixing of ingredients, providing optimal conditions for final restoration with its added hemostatic and fixative properties.

However, in the present study, Pulpotec application was simple, time-saving, and affordable and showed $100 \%$ clinical and radiographic success rate in a six-month period. This high success rates may be due to the anti-inflammatory, disinfectant, and steroidal properties of the material.

A study conducted comparing the clinical and radiographical success rates of formocresol, MTA, Pulpotec, and Emdogain showed 100\% clinical and radiographical success at the end of six months. By the end of 24 months' follow-up, the clinical success rates of FC and Pulpotec were 94.4\%, EMD was 83.3\%, and MTA was $100 \%[12]$.

In the never-ending quest for an ideal pulpotomy agent, this study has tested three materials. Even though there was reasonable clinical and radiographical success with all the three materials, Pulpotec showed a higher success rate. Studies with long-term follow-up are needed to establish the ideal pulpotomy medicament.

\section{Conclusions}

At the end of the study, it was observed that Group III (Pulpotec) exhibited the overall best results as the pulpotomy agent for primary molars followed by Group II (Biodentine), whereas Group I (MTA) showed the least favorable results, both clinically and radiographically. In order to get more authentic results, detailed longitudinal studies involving bigger samples and larger follow-ups are needed.

\section{Additional Information \\ Disclosures}

Human subjects: Consent was obtained by all participants in this study. Institutional Ethical Committee, Lenora Institute of Dental Sciences issued approval 45/IEC/LIDS/2016. The institutional ethical committee, LIDS, has reviewed and discussed your protocol on 24-11-2016 to conduct the research project entitled "Evaluation of radiological outcomes of pulpotomized primary molars treated with three different materials : MTA, Biodentine, Pulpotec - An invivo study". On behalf of the committee, I am pleased to confirm a favourable ethical opinion for the above research provided that you comply with the following conditions. Please note that IEC must be immediately informed of; - any serious adverse event that occurs during the conduct of the study - any material change in the conditions are undertakings mentioned in the document any material breaches of ethical undertakings or events that impact upon ethical conduct of the research The research must report to the IEC annually, and at the end of the project in respect of ethical compliance. Animal subjects: All authors have confirmed that this study did not involve animal subjects or tissue. Conflicts of interest: In compliance with the ICMJE uniform disclosure form, all authors declare the following: Payment/services info: All authors have declared that no financial support was received from any organization for the submitted work. Financial relationships: All authors have declared that they have no financial relationships at present or within the previous three years with any organizations that might have an interest in the submitted work. Other relationships: All authors have declared that there are no 


\section{References}

1. Kumari KK, Sridevi E, Sai Sankar AJ, Gopal AS, Pranitha K, Kumar MG: In vivo evaluation of honey as a new medicament for vital pulp therapy in primary teeth. SRM J Res Dent Sci. 2017, 8:58-63.

2. Platonova SA, Zhuralev ON, Kartoshkin AA, Petrikas OA, Petrikas AZ: Vital pulpotomy and its perspectives. Ann Rev Resear. 2018, 3:555-565.

3. Berger JE: Pulp tissue reaction to formocresol and zinc oxide-eugenol. J Dent Child (Chic). 1965, 32:13-28.

4. Holan G, Eidelman E, Fuks AB: Longterm evaluation of pulpotomy in primary molars using mineral trioxide aggregate or formocresol. Pediatr Dent. 2005, 27:129-136.

5. Srinivasan D, Jayanthi M: Comparative evaluation of formocresol and mineral trioxide aggregate as pulpotomy agents in deciduous teeth. Indian J Dent Res. 2011, 22:385-390.

6. Borkar SA, Ataide I: Biodentine pulpotomy several days after pulp exposure: four case reports . J Conserv Dent. 2015, 18:73-78.

7. Niranjani K, Prasad G M, Vasa AAK, Divya G, Thakur MS, Saujanya K: Clinical evaluation of success of primary teeth pulpotomy using mineral trioxide aggregate, laser and Biodentine ${ }^{\mathrm{TM}}$ - an in-vivo study. J Clin Diagn Res. 2015, 9:35-37. 10.7860/JCDR/2015/13153.5823

8. Kaur M, Singh H, Dhillon JS, Batra M, Saini M: MTA versus Biodentine: review of literature with a comparative analysis introduction. J Clin Diagn Res. 2017, 11:01-05. 10.7860/JCDR/2017/25840.10374

9. Faraj BM: Four years of clinical experience with the efficacy of Pulpotec as a root canal dressing for the management and control of odontogenic pain: a prospective randomized clinical trial. Oral Health Dent Manag. 2013, 12:527. 10.17656/jzs.10269

10. Kakarla P, Avula JS, Mellela GM, Bandi S, Anche S: Dental response to collagen and Pulpotec cement as pulpotomy agents in primary dentition: a histological study. J Conserv Dent. 2013, 16:434-438.

11. Donskaya IP, Dedeyan SA: Treatment of odontitis in pediatrics by method of vital amputation with use of 'Pulpotec'. Transactions of the VIII Congress of the Dentists Association of Russia, Moscow. 2003, 287-288.

12. Sunitha B, Puppala R, Kethineni B, Mallela MK, Peddi R, Tarasingh P: Clinical and radiographic evaluation of four different pulpotomy agents in primary molars: a longitudinal study. Int J Clin Pediatr Dent. 2017, $10: 240-244$. 